\title{
Application of the biocenotic tree assessment method in the "Vila Mîndîc" park (Moldova) for the implementation of a conceptual land-use project - a case study
}

\section{Lidia Ozimkowska, Jerzy Wojtatowicz}

\begin{abstract}
The article presents the aplication of the biocenotic tree assessment method in the "Vila Mîndîc" park (Moldova). While conducting the inventory, preliminary design decisions were taken into account, which also influenced the determination of tree values. By extending the plant valorisation to the study of health, including safety for humans, the results were obtained to carry out the project. Particular areas were selected, which regardless of the conditions, must ensure safe stay; parts of the area where visiting the park is restricted and those where, due to high biocenotic values (including protection of animal breeding and nesting sites) communication routes and leisure areas are not planned. On the basis of the research, areas of exceptional importance for animals were identified and a conceptual land development project was carried out to accommodate human recreational needs.
\end{abstract}

Key words: landscape architecture, dendrology, biocenotic values of trees, natural connections

\section{Introduction}

Two publications related to this article appeared in the scientific periodical "MAZOVIA Regional Studies" - issues 18/2016 and 32/2020. First of them, entitled "Vila Mîndîc park and palace as a special landscape element and its structural transformation as the sign of time", concerns the historical park located in Moldova. The second article, "Proposal to change the assessment of trees in landscape architecture", describes the method of biocenotic valorisation of trees, which can be carried out as part of pre-design works of natural objects with the main leisure function. The presented method distinguishes three categories of assessment of the biocenotic values of trees, which result from: 1) individual features, 2) connections with the immediate surroundings and location in the park and 3) location in relation to ecosystems outside the park. Based on the scoring, a tree can be classified into one of the groups of a specific biocenotic value. This method is presented in two variants. Each of them provides the criteria for the assessment of trees in descriptive and numerical form. The three-point scale evaluation variant is used in classic studies with limited project implementation time. The five-point scale assessment option is suitable for multidirectional research of the area, conducted by 
experts in various fields concerning the natural and cultural values of the landscape. In this case, the work should be carried out in two stages. At the first stage, each expert evaluates the components or features of the landscape in the field of his specialization. At the second stage, works are carried out by the entire team with the participation of a landscape architect. A synthesis of all the results is carried out, the conclusions of which are used to draw up guidelines for the design of a landscape architecture facility.

In 2014, on behalf of the Polish Ministry of Culture and National Heritage, the Cultural Heritage Foundation - a Polish social organization dedicated to the protection of monuments, together with the Moldavian side $^{1}$, organized study trips for experts in various fields, including surveyors, art conservators, architects, landscape architects. The authors of this article were responsible for coordinating pre-project studies, their analysis and synthesis, as well as the preparation of a land-use concept taking into account its own natural research and guidelines resulting from historical [Michałowski, Werner 2014] and construction-architectural research conducted by the Technical University of Moldova in Chişinău. Together with Robert Jancelewicz and Andrzej Szczepanik, students of Landscape Architecture at $\mathrm{UEM}^{2}$, a study on the dendrological inventory and park's tree stand management was carried out, taking into account the method of biocenotic valorisation of trees. These studies were used to prepare a conceptual design of "Vila Mîndîc" area development.

\section{Goal and scope}

The aim of this article is to show the problems that occurred when applying the method of biocenotic valorisation of trees in the historical park. The scope of the study includes a definition of biocenotic plants; an explanation of the principles of tree categorization in the applied method; the specificity of the terrain which significantly influenced the conducted research; an outline of the problems occurring with the method used to carry out the project; a conceptual design of the land-use development. The supplementary aim of the paper is to popularize the biocenotic tree assessment method developed by the authors.

\section{The definition of biocenotic plants in relation to the method of valorisation}

As stated in the article, describing the method of biocenotic valorisation of trees [MAZOVIA Regional Studies 18/2016], "trees, shrubs and other biocenotic plants shall be considered to be of particular importance for the life and development of other organisms.

\footnotetext{
${ }^{1}$ The first works on the restoration of the historic complex, in which the Polish side participated, started in 2002. The representative of the Ministry of Ecology from Moldova and director of the Board of Protection and Conservation of the Palace and Garden Ensembles of the National Museum in Poland, signed an agreement on the reconstruction of the Mîndîc park. In 2012, an expert team from Poland (PhD Andrzej Michałowski, MA in Art History Barbara Werner, MSc Eng, Architect Kinga Dujanowicz) visited Moldova to inspect the actual state of the establishment of "Vila Mîndîc".

${ }^{2}$ University of Ecology and Management in Warsaw.
} 
These plants can be a life habitat for other plants, funguses and lichens, as well as provide animals with food, shelter or be used as breeding sites. The value of these plants is due to the biological characteristics of the species, individual features and location in the landscape. Both the immediate neighbourhood and the location in relation to neighbouring ecosystems are important. (...) Biocenotic trees, shrubs, and climbers can satisfy one life need of other species over a short period of time or multiple needs, even for many years. Taking into account the biocenotic value of a tree, its suitability for one particular organism that is in danger of extinction, which could be the essence of a tree valorisation according to the nature protection, is not highly assessed. The most essential thing is the importance of the tree in its habitat." Nature monuments, protected, rare and endangered species are of great importance for nature protection as a broader term. They are classified as trees of special importance which, if they create the conditions for life and development of many other species, should also be classified as biocenotic trees. However, that does not mean that expansive tree species that degrade the ecosystem or those that encourage the growth of species that reduce the value of the entire assemblage will be rated high, even though their value assessed in isolation from the environment could be defined as high.

Valorisation of trees with the biocenotic method, as a qualitative study, does not make it possible to draw comparative conclusions and present them, e.g. in numerical form. It does not answer the questions "how many trees have the given values" and "how often do biocenotic plants occur", but it can be used to answer the question "how to evaluate the tree utility for flora and fauna" and "why do we classify a tree in a specific group". The results of the study cannot be generalized as they are not representative for all landscape architecture objects. Each considered object is different and for these reasons the described method can be given as an example of a procedure, but it should be subjected to a critical analysis and sometimes modified for a specific situation before its application. It does not show the generality of the phenomenon of the occurrence of biocenotic values, but only its diversity. There can be a problem with categorization, especially in the initial stages of conducting research, before the evaluator achieves certain skills. The results of such studies do not necessarily lead to simple interpretive conclusions. Preservation of natural or cultural values under legal protection is indisputable. Nevertheless, many of the values existing in parks, even those perceptible, such as biocenotic value, have not been provided with methods that would make it possible to individualise and include them in further stages of the design process.

\section{Categorization of trees as a method for assessing biocenotic value}

Three categories of tree biocenotic value assessment were distinguished in the presented method. For the categorization of trees, it is important that the described method does not take into account the potential biocenotic value of the species, but the value of individual specimens [Wojtatowicz 2010].

The first category includes the individual features of the tree. These are biological traits (such as the thickness and depth of bark, abundant fruiting and crown density) that are 
conducive to the life and development of native animal, plant and fungal species. They may also derive from acquired features such as hollows, mistletoe in the crown or climbers wrapping the trunk.

The second category shows the biocenotic value resulting not only from the individual features but also from the relation with the nearest environment, i.e. the sites where particular specimens grow. Even trees with very similar individual characteristics can differ greatly in their biocenotic value. Thus, one tree may grow away from human and vehicle traffic, penetration by dogs and cats, while another may grow in areas with dense infrastructure that are heavily used near buildings, gateways, roads, playgrounds, etc.

The third category refers to the location of the tree in relation to the park boundary and its position in relation to ecosystems outside the park. As in the first and second category, the value of a tree results from its individual features, but also from the dependence of the land use outside the park boundary, which is practically beyond the control of both the owner and the designer. One neighbour may use the land in a manner that promotes nature protection, while another may carry out activities that impoverish natural values on its territory and in the nearest surrounding. In this regard, the individual value of trees may be similar and the value to the biocenosis may be extremely different. Thus, a tree with comparable characteristics may be classified differently depending on the presence of other factors seemingly unrelated to it.

\section{Specification of the study area}

\section{Historical and legal conditions}

The manor-park complex from 1896 [Pasport Pamâtniki istorii i kultur SSSR] is located on the territory of today's Moldova, in the northern part of Bessarabia, between two villages: Mîndîc and Cotova. The nearest town named Drochia is $25 \mathrm{~km}$ to the southwest. The total area of the entire site is $17,500 \mathrm{~m}^{2}$. The founder was Kajetan Oganowicz (Ohanowicz) (17911874) [Soloveva 2002], Polish nobleman of Armenian origin [Theodorowicz 1925], who built a manor house surrounded by greenery [Terrace 1986] and then modernized it in cooperation with Alexander Bernardazzi (1831-1907), a prominent Bessarabian architect. The result of this collaboration was a residence in the valley of a watercourse with numerous ponds, surrounded by hectares of farmland. The park "Vila Mîndîc" was placed under protection in 1962 [Leontev 1967; Kravčuk 1972]. In 1975 the Council of Ministers of the Moldavian Soviet Socialist Republic gave it the status of a natural monument and to this day, despite much neglect, it enjoys the attention of the authorities. In 1997 the park was included in the register of monuments of Moldova [Monitorul Oficialal. Republicii Moldova, 18, 20 martie 1997, MOLDPRES]. "Vila Mîndîc" became a branch of the National Museum of Ethnography and Natural History in Chişinău and the museum "Villa with Mîndîc Park" was established there [www.dziedzictwo.org / Działalność / zespół-dworsko-parkowy-vila-mindic-moldawia]. In 1998 the park was included on the list of Landscape Architecture Monuments. 


\section{Natural conditions}

The area designated for protection in 1975 covered 10 hectares and was valuable due to the presence of 35 kinds of trees and shrubs, including 20 exotic ones, orchards, ponds, the building of the villa and the Ohanovichs' chapel [Pasport Pamâtniki istorii i kultur SSSR]. This condition did not change until the 1990s, as evidenced by the inscription in the plaque entitled "Historical Characteristics and Contemporary Condition of Old Parks of Moldova" [Dormidontova 1992]. An inventory study in 2014 confirmed the presence of 30 types of trees and shrubs [Ozimkowska, Wojtatowicz, Szczepanik 2015]. The most numerous are ash trees: Pennsylvanian Fraxinus pennsylvanica, American F. americana, and common ash F. excelsior, including the variety F. e.'Elegantissima', maples: the common Acer platanoides, field A. campestre and silver A. saccharinum, Robinia pseudoacacia, willows: weeping Salix x sepulcralis 'Chrysocoma' and brittle $S$. fragilis, birches Betula and conifers: common spruces Picea abies and black pines Pinus nigra. From fruit trees: Malus apple trees, cherry trees, Prunus plum trees. The hornbeam avenue is distinctive. Occasionally the white mulberry Morus alba, the late birdcherry Prunus serotina, the narrow-leaved olive Eleagnus angustifolia and the glandular ailanthus Ailanthus altissima have been noted. Currently, the "Vila Mîndîc" park has exceptional natural values: 70 pieces of century-old trees (over 100-year-old trees), numerous rare species of insects, and among amphibians, apart from green frogs, there is a rare rich site of the fire-bellied toad Bombina bombina. Apart from the green-coloured tree frog Hyla arboreta, there are also brown steel and beige-coloured specimens. The park ponds are habitat for a population of the pond turtle Emys orbicularis. It is important that rare and attractive birds can be observed in the park, e.g. common bee-eater Merops apiaster, kingfisher Alcedo atthis, green woodpecker Picus canus, woodpecker Dryobates minor, numerous raptors such as Falco vespertinus, buzzards, eagles.

Noteworthy are populations of mammals such as common weasel Mustela nivalis, speckled ground squirrel Spermophilus suslicus, bats. The park's unusual value is evidenced by several large nests of raptors, which at certain times are occupied by the common raven Corvus corax. It is worth emphasizing that this park is an enclave of tree stands in the agricultural landscape, surrounded by ponds.

Its unique location, biotope features (especially the local climate, unusual fertility of soils or hydro-graphic layout) and many years of cessation of intensive recreational and leisure activities have made this area of outstanding natural value and a refuge for many species, including predators hunting rodents in the surrounding fields. The park is also an important link on the local animal migration route.

\section{Recreational conditions}

The air in the park is well-humidified. Thanks to the proximity of water bodies and the canopy of spreading trees its temperature in summer is reduced. The tree stand retains the dispersing dust and plant protection chemicals grown outside the park. In winter, the 
temperature is higher and winds are less bothersome. During the growing season, the air is saturated with a variety of smells compared to the homogeneous smells of the surrounding monoculture crops. The water table of the ponds and the flowing seasonal streams, which sometimes make the landscape more dynamic, are attractive.

There is a negative perception of muddy bottom, dusty water with a tendency to overgrow. This is most evident on the southern and southwestern shores of a large reservoir in areas where the slopes turning into to the banks are exposed to strong sunlight and the water is shallow and warm. In contrast, shallow waters with large deposits of suspended solids carried from the gorge show less tendency to overgrow, mainly as a result of shading and lower temperatures. Similar overgrowth trends occur in the smaller pond behind the causeway. The reservoir, into which the seasonal stream flows, is completely overgrown due to water erosion of the fertile fields outside the park (black soil), fertilized with mineral fertilizers, and due to strong sunlight. It creates the ideal conditions for the development of the fire-bellied toad, which occurs here in unprecedented numbers. Excess water from this reservoir flows through the gorge into a large forked pond. Water in the seasonal stream attracts attention, especially during high flows, when the bottom and the banks are eroded, roots of trees growing on the slopes emerge and uproots are formed. These phenomena can be observed from the bridge in the hornbeam alley (former hedge) leading towards the burial chapel and from the path along the stream. During periods of high humidity, park soils are slippery, sticky to shoes and making it difficult to move around. During the drought periods, they are heavily cracked and dusty. The great recreational value of the area is due to the presence of many attractive animal species. They enliven the landscape of the park with their coloration, voice or sounds and movement. Among animals there are many interesting species: from insects dragonflies and butterflies, fish attractive for potential anglers. Apart from typically colored amphibians, frogs of various colors (beige, light and dark brown, steel and black) and mostly green frogs with lower back and hind legs in various shades of brown and grey were found here. The fire-bellied toad Bombina bombina attracts attention during the breeding season with its intense sound, which in this modulation can be not only delightful but even tiring. The sand lizard Lacerta agilis lives here, as well as the large population of the pond turtle Emys orbicularis, which is valuable from a nature protection and recreational point of view and could itself become a trip destination. In May 2015, eight adult individuals were observed simultaneously on the edge of the reed and 21 individuals were observed in the reeds of the fishpond bordering the park. Among the birds, attention is drawn to the white herons Ardea alba and grey heron $A$. cinerea, eagles and ravens Corvus corax, characterised by their color: bee-eaters Merops apiaster, kingfishers Alcedo atthis, jays Garrulus glandarius; singing: grey nightingales Luscinia luscinia, blackbirds Turdus merula, cuckoos Cuculus canorus, reed warblers Acrocephalus arundinaceus, chaffinches Fringilla coelebs, Linaria cannabina; flight dynamics: red-footed falcon Falco vespertinus, common swift Apus apus, spring swallows Hirundo rustica, kingfishers, bee-eaters and gliding buzzards, eagles and lesser spotted eagles. Trees with broad crowns giving a lot of shade, among which there are glades, clearings for water mirrors/tables are not only picturesque, but also provide a favorable microclimate. This is a great value due to the location of the park among the fields. The park gives an opportunity 
to admire trees of unique dimensions; the height of some Canadian poplars Populus $x$ canadensis, ash Fraxinus excelsior and even black walnut Juglans nigra grows up to $23 \mathrm{~m}$, and the diameter of crowns of brittle willows Salix fragilis exceeds $20 \mathrm{~m}$. Many species of funguses, both on trees and in the ground, have attractive fruiting bodies. The park is not open to the public, which contributed to the creation and maintenance of the described unique values that qualified it to apply the extended - five-stage - version of the biocenotic method during the research.

\section{Adaptation of the research method to the specifics of the park}

Due to the consideration of the possibility of adapting the "Vila Mîndîc" area to the needs of the international center of national borderland in Moldova [Dunayevich, Werner 2013] or the educational museum and didactic area [Michalowski, Werner 2014], pre-project analyses were carried out in a number of ways. Already the first visit to the park showed that fragments of the original structure of the former Ohanovichs' garden, containing traces of the functional and compositional system, as well as individual elements that have survived to the present day have high natural and cultural value. This was an impulse to search for appropriate methods that would preserve the existing values as much as possible. One of the most urgent needs was to develop a method that would allow the valorisation of trees, as it was found that there are many species in the tree stand, responsible for the rich state of the biocenosis. They enable, through their individual features, the life of many species and provide a protective umbrella for them (Fig. 1). ${ }^{3}$ The analysis of the biocenotic value of trees was one of many that, only in relation to others, made it possible to distinguish areas with different leading functions. The biocenotic value of the trees in this case was determined a bit differently than it was described in the previous article, because the area was not treated as a typical recreational park, but as an area intended for recreation, which is protected at the same time. These restrictions made the location of the trees in the park much more important. This factor in landscape architecture objects should be treated equally with other factors such as individual or acquired tree characteristics.
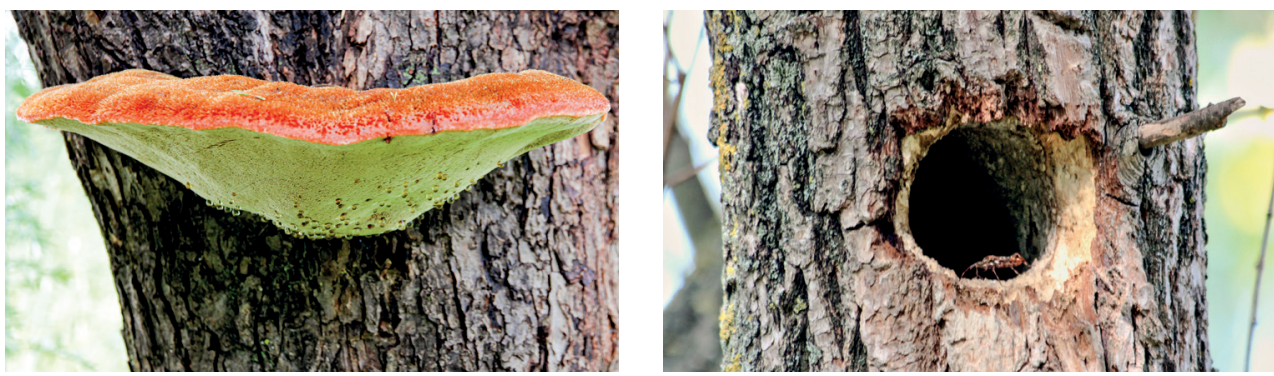

Fig. 1. Trees with acquired biocenotic value as a habitat for living organisms

a) The tree as a habitat for funguses, b) The tree with a hollow used by insects after the birds' breeding season

\footnotetext{
${ }^{3}$ Jerzy Wojtatowicz is the author of all the photographs in the article (Figs. 1-6).
} 
Taking into account the priority recreational function of the facility, it was assumed that the protection of natural and cultural resources should be treated in a special way in relation to the other accompanying functions. This results not only from legal regulations, but also from the expected increased anthropopression after the facility has been made available for use. The results elaborated on the basis of the description of the biocenotic tree assessment method [see: MAZOVIA Regional Studies 32, 2020] show the existing values and only to a small extent the potential values, which led to modification of the applied method. It is a known fact that some trees will lose value due to natural processes, such as complete wood decay or human activity in shaping the designer's target vision. Thus, trees that have the potential to thrive to increase their natural value were rated higher so that they would not be eliminated accidentally. The assessment was performed by landscape architects who were aware of the direction of the changes proposed in the project and were aware that in areas where recreational traffic will be concentrated the biocenotic value of trees and other natural elements will decrease. Trees of unique value should be preserved and tourist traffic should be limited. When assessing individual trees, their value was raised or lowered depending on their location in the park. Trees located in the edge zone of the tree stand - in the outer boundary (Fig. 2) or in the edges between different aggregations (Fig. 3) received additional points. Trees with exceptional values, such as trees with large raptor nests (Fig. 4), were rated the highest. Some trees were downgraded in biocenotic value due to their location in the intensive use zone, e.g. in the central part of the park next to a building or an entrance alley (Fig. 5). Analysing the position of trees in the park structure and other landscape values, areas were separated in terms of different value.
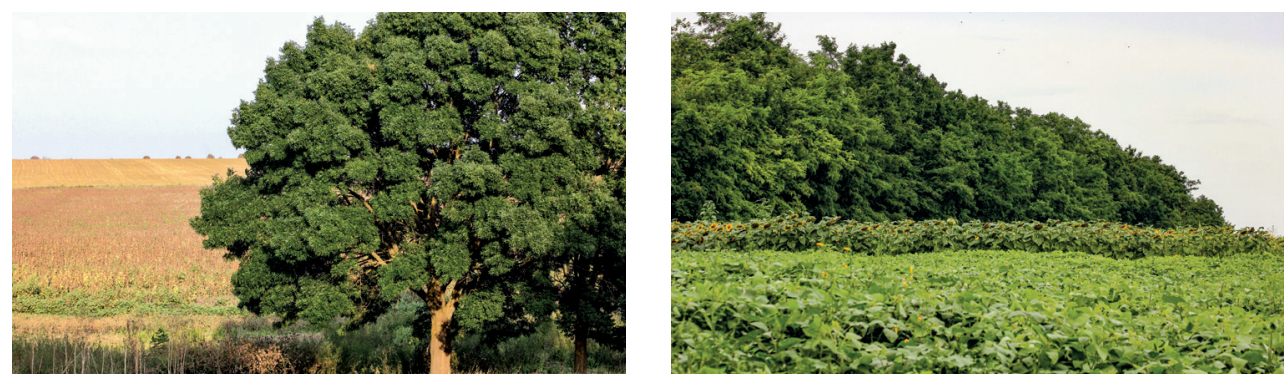

Fig. 2. Trees with increased biocenotic value located in the outer fringe of the park
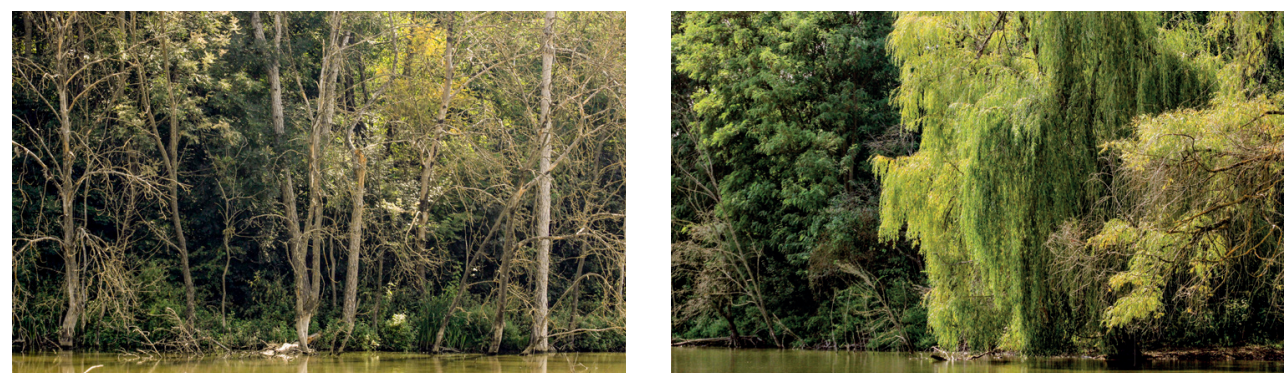

Fig. 3. Trees with increased biocenotic value located in the inner fringe of the park 

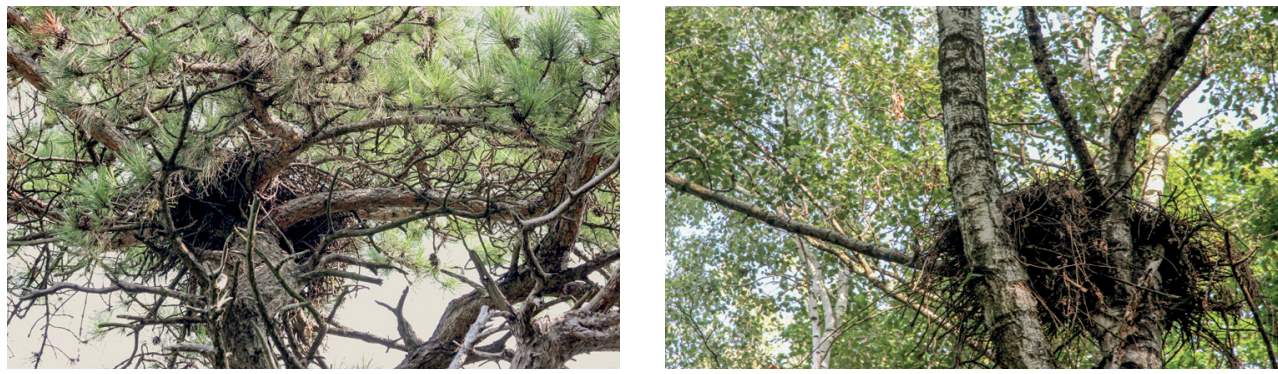

Fig. 4. Trees with highest acquired biocenotic value located in the park. Old nest alternately occupied by raptors or ravens
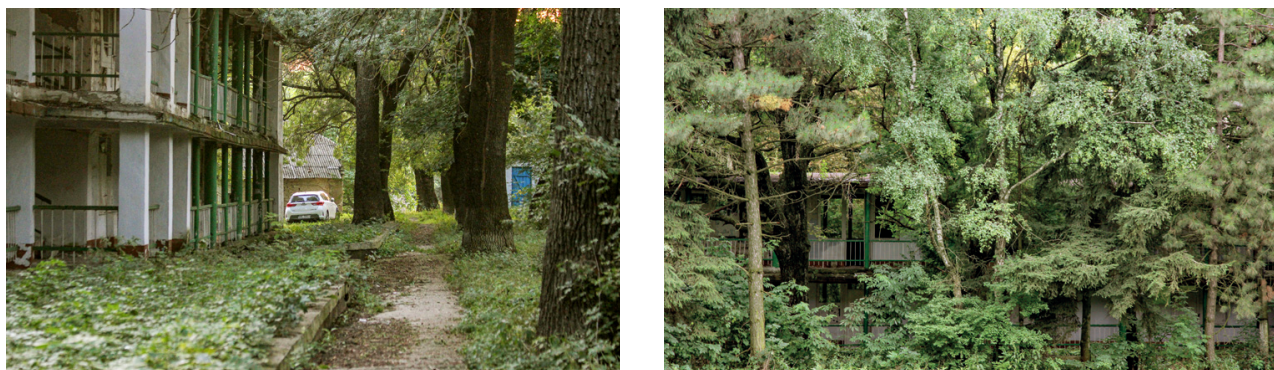

Fig. 5. Trees with reduced biocenotic value due to their location in the intensive use zone in the central part of the park

In the "Vila Mîndîc" park it is not necessary to restore the biocenotic value to the degraded area, which is the main goal of all pro-ecological activities widely described in recent years, when these values are not only identified but also exposed. The trend of revitalization or renaturalization ${ }^{4}$ is becoming more and more widespread. Also in newly designed parks, enclaves valuable for flora and fauna are separated, but we very rarely deal with values unique on a national or even European scale, as undoubtedly the natural resources of the "Vila Mîndîc" park can be described.

This park has high biocentic values mainly due to the surrounding vast cultivated fields devoid of large old trees (Fig. 6). During the valorisation, trees were also assessed in terms of their health conditions and nature protection [Ozimkowska, Wojta-

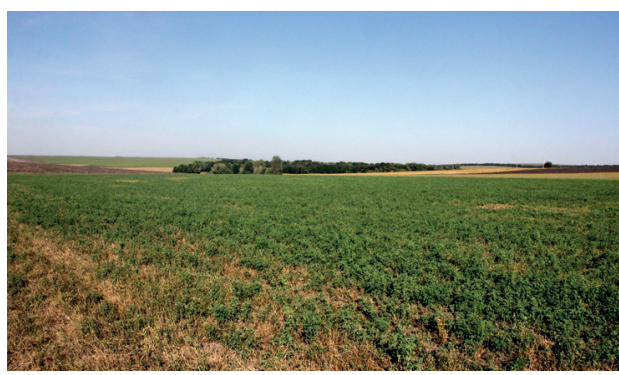

Fig. 6. Location of the "Vila Mîndîc" park in the agricultural landscape towicz, Jancelewicz 2014]. The assessment

\footnotetext{
${ }^{4}$ See: Park on the islands in the Netherlands 2001-2008, Parc de Saint Jacques de la Lande, Ille-Vilaine, France 2007-2013, which won the top prize for wetlands in urban areas in 2012) [http://www.brueldelmar.fr/fr/project/ 22 / parc-ecologique-de-saint-jacques].
} 
was conducted by a three-person team, one of whom specialized in health assessment, the other assessed the tree in terms of its biocenotic and nature protection value. The tree was assessed taking into account its individual biological and acquired features, its connections with the immediate surroundings and its location in the park and position in relation to ecosystems outside the park. The third person coordinated and controlled the results, which was important in view of the large number of trees being evaluated simultaneously in three aspects. Valorisation was based on the research objective, which in this case was to determine the usefulness of the analysed trees for the flora and fauna of the site in a specific period of time, but its results have a reference to other aspects, such as conceptual land-use project. The biocenotic value determined at the inventory stage may be transformed after introducing changes in the surroundings of the examined tree. Often revalorization, modernization and even care treatments reduce the natural value of the object or its fragments instead of preserving and restoring it. Numerous comparative studies of natural resources of parks before and after their renovation show their impoverishment [Luniak, Wegrzynowicz 2019; Popko 2008]. In order to avoid the risk of transforming a valuable natural area into a typical landscape architecture object, where the main function is people's recreation, and other functions are defined as accompanying, the results of the assessment of both the biocenotic value of trees and their health condition were used. The assessments performed separately only after comparing in one table with reference to the location on the geodetic base and the design concept allowed for the final assessment; e.g. a rotten tree with high biocenotic value was qualified to be left when it was located in an area not accessible to people, while when it grew in a place of high penetration, it had to be cut down in the final evaluation.

\section{Tree assessment method in "Vila Mîndîc" park}

The tree stand inventory was performed from July 21 to 30 and from September 1 to 9, 2014. The chamber works were completed on October 10, 2014. The results of the study are presented in graphic and descriptive form (in the table). If a measurement is not possible, only the name of the tree is given in the table. The dendrometric measurements performed in the scope of the basic inventory, which concerns the determination of the type and species of a tree, its height, trunk circumference and crown spread, were extended by the description of the tree health condition and its biocenotic value. The individual data were defined as follows:

- $\quad$ Tree height with the Nikon Laser Forestry Pro altimeter

- Trunk circumference with the measuring tape at a height of $=130 \mathrm{~cm}$

- Crown spread with the measuring tape.

- The health condition of the tree was determined by a four-point scale and was marked with letters A-D, where:

A - fully developed form of a tree (trunk, crown), characteristic for the species. Vitality phase (ac-cording to Roloff) - FW0, FW1. No visible signs of disease or pathogens. Dead wood to $5 \%$. 
B - tree with visible defects within the trunk and the crown, with the possibility of their reconstruction. Vitality phase FW1, FW2. Dead wood to $25 \%$.

$\mathrm{C}$ - visible minor surface defects on the trunk. Crown reduced or heavily thinned, with a possibility of partial reconstruction. Dead wood to $50 \%$.

$\mathrm{D}$ - visible signs of disease and pathogens (primary and secondary). Large cavities in the trunk. Crown strongly reduced without the possibility of regeneration. Vitality phase FW3. Dead wood over 50\%. A tree that is dying or dead.

Roloff Scale:

FW0 - exploration phase - intense development

FW1 - degeneration phase - weakened development

FW2 - stagnation phase - no development

FW3 - resignation phase - dying out

- The biocenotic value and importance for nature conservation were determined using a five-point scale and were marked with Roman numerals I-V, where:

I - a tree growing in direct proximity to human settlements, busy pedestrian routes and in places intensively penetrated by people. It grows deep inside the tree stand and is one of the specimens of a large monoculture group. It does not stand out from its surroundings in terms of size and structure. The crown is thinned. Lack of hollows and other places usable for shelter, rest, breeding and procreation of animals of considerable size. Species, especially if of foreign origin (e.g. ash-leaf maple), belongs to the expansive group, limiting the development of local fauna and flora. Low value in terms of benefits, especially food for many animal species.

II - a tree growing in close proximity to human habitats, pedestrian routes and places penetrated by people. It grows deep within the tree stand and is one of the specimens of the monoculture group. It does not stand out from its surroundings in terms of size and structure. The crown is thinned. Lack of hollows and other places surroundings for shelter, rest, breeding and procreation of animals of considerable size. Species, especially if of foreign origin (e.g. ash-leaf maple), belongs to the expansive group, limiting the development of local fauna and flora. Low value in terms of benefits, especially food for many animal species.

III - a tree grows on the sidelines of human settlements, pedestrian routes and in places rarely penetrated by people during the breeding and procreation period. It grows in the depth of a tree stand or in a small monoculture group. It does not stand out from its surroundings in terms of size and structure. Limited number of places usable for shelter, rest, breeding and procreation of animals of considerable size. A species does not have a significant impact on the development of local fauna and flora. Average value in terms of benefits, especially food for native animal species.

IV - the tree grows outside the zone of intensive penetration during the period of animal breeding and procreation, and lush development of undergrowth and underbrush. It stands out from its surroundings in terms of size and structure. Large number of potential places usable for shelter, rest, breeding and procreation of animals of considerable 


\section{APPLICATION OF THE BIOCENOTIC TREE ASSESSMENT METHOD IN THE "VILA MÎNDÎC"}

Lidia Ozimkowska, Jerzy Wojtatowicz

size. Native or non-expansive species of foreign origin, enabling the development of native fauna and flora. Significant value in terms of benefits, especially food for many animal species.

$\mathrm{V}$ - the tree grows in a zone of year-round minimal human penetration, solitary or on the edge of the tree stand. It is a natural valuable component of the native plant collection. It stands out from its surroundings in terms of size and structure. The crown and trunk with hollows are favourable for building nests and other places of procreation, as well as shelter and rest for animals of considerable size. Very high value in terms of benefits, especially food for native animal species. The species belongs to the native, rare or protected flora.

\section{General results of the assessment of the health condition and biocenotic value of trees in the "Vila Mîndîc" park in Moldova}

The study of the extended dendrological inventory and valorisation, the results of which are summarized in the table (Fig. 7) ${ }^{5}$, was carried out on 1400 individuals. The highest biocenotic value (V) was recorded for 181 trees, which represent $13 \%$ of the resources. Among them, the most numerous group are ash trees, maples, willows and hornbeams. Comparing the trees of the highest biocenotic value with their health condition: only three trees were qualified to the highest health condition category marked with letter A, 56 trees were qualified to category $\mathrm{B}$ as trees with visible defects in the trunk and crown with the possibility of their reconstruction. 70 trees were assigned to category C, i.e. trees with minor surface defects on the trunk. The crown is reduced or strongly thinned, with the possibility of partial restoration. 53 trees were classified as decaying or dead in D category without the possibility of regeneration.

\begin{tabular}{|c|c|c|c|c|c|c|c|}
\hline \multirow{3}{*}{\begin{tabular}{|c|}
$\begin{array}{c}\text { number } \\
\text { on } \\
\text { the map }\end{array}$ \\
1 \\
\end{tabular}} & \multicolumn{7}{|c|}{ Assessment of health condition and biocenotic value of trees in "Vila Mîndîc" park in Moldova } \\
\hline & \multicolumn{2}{|c|}{ species } & \multirow{2}{*}{\begin{tabular}{|c|}
$\begin{array}{c}\text { circumference } \\
{[\mathrm{cm}]}\end{array}$ \\
185
\end{tabular}} & \multirow{2}{*}{$\begin{array}{c}\begin{array}{c}\text { crown } \\
\text { diameter }\end{array} \\
9\end{array}$} & \multirow{2}{*}{$\begin{array}{c}\text { height } \\
8.0 \\
\end{array}$} & \multirow{2}{*}{$\begin{array}{c}\begin{array}{c}\text { health } \\
\text { condition }\end{array} \\
\text { B }\end{array}$} & \multirow{2}{*}{$\begin{array}{c}\begin{array}{c}\text { biocenotic } \\
\text { value }\end{array} \\
\text { III }\end{array}$} \\
\hline & Norway maple & Acer platanoides & & & & & \\
\hline 2 & common ash & Fraxinus excelsior & $40+108$ & 10 & 8.0 & $\mathrm{C}$ & III \\
\hline 3 & common ash & Fraxinus excelsior & 60 & 9 & 8.0 & C & I \\
\hline 4 & green ash & Fraxinus pennsylvanica & $87+87$ & 7 & 7.5 & C & II \\
\hline 5 & brittle willow & Salix fragilis & $226+217$ & 17 & 10.5 & C & IV \\
\hline 6 & field maple & Acer campestre & 23 & 11 & 9.0 & C & IV \\
\hline 7 & common pear & Pyrus pyraster & 70 & 5 & 9.0 & B & IV \\
\hline 8 & Norway maple & Acer platanoides & 113 & 12 & 11.0 & $\mathrm{~B}$ & III \\
\hline 9 & bird cherry & Prunus avium & 90 & 6 & 12.0 & A & IV \\
\hline 10 & Norway maple & Acer platanoides & 88 & 7 & 12.0 & $\mathrm{~B}$ & II \\
\hline 11 & bird cherry & Prunus avium & $95+70$ & 8 & 9.0 & C & IV \\
\hline 12 & apple tree & Malus domestica & 70 & 5 & 4.0 & C & II \\
\hline 13 & cherry plum & Prunus cerasifera & $28-86$ & 9 & 6.5 & C & III \\
\hline
\end{tabular}

Fig. 7. An exemplary record card of assessment of health condition and biocenotic value of trees

\footnotetext{
5 Tomasz Wojtatowicz is the author of all the illustrations in the article (Figs. 7-10).
} 
The research problem that arose did not result from the method of assessment, but from its proper interpretation. The method used is not problematic when performed by a person who does not analyse the results. Considered as an extended survey, the tree inventory is an appropriate tool leading to clearly defined conclusions, assuming that no change in land use is expected, but only its monitoring. At the moment when the results are being interpreted, the descriptive data itself and especially the numerical ones, cannot be automatically translated into design decisions regarding the change of land use.

\section{Use of pre-design analyses to clarify design guidelines}

The biocenotic tree assessment method turned out to be highly useful in the development of the land use concept at "Vila Mîndîc". It should be stated that it is not always necessary to assess the biocenotic value of trees. When the leading function is nature protection, e.g. in nature reserves or nation-al parks, usually the location of a tree has no significant influence on the assessment of its value, because it is inherently protected and does not require valorisation. The situation is similar when the designer does not take into account the biocenotic value of trees, but is guided only by the investor's needs, financial possibilities and modern design trends (aesthetic, compositional, functional, material, etc.). It can also happen that the designer has a general knowledge of the individual biocenotic value of a tree, but his goal is not the analysis of the consequences that will result from the implementation of the project. In these cases the nature protection is marginalized and the ethical problem of diminishing or destroying the value goes unnoticed. The biocenotic values after project implementation will be a matter of chance. Knowing the placement of important sites and biocenotic values, it is already possible at the assessment stage to estimate the gains and losses caused by the implementation of the main goal. In such a case, there is a better chance of protecting the natural values, as the value of each tree is assessed comprehensively, e.g. human safety is taken into account. In this way, information is obtained not only about the value of the tree from the recreational point of view, but also about the losses caused by the reduction of the natural value of the entire facility. Thus, design tools can compensate, to some extent, for the damage caused by intensive recreational use. The tree inventory, correlated with the assessment of their health and biocenotic value, as well as the presence of special natural and historical elements, was used to create a plan showing a simplified graphic layout of areas divided into three categories (Fig. 8). The scheme presents general guidelines for the revalorization project, taking into account both the effects of profound transformations, the immaterial and the material sphere. These include changes in land use, type of space, basic functions of the facility, nature, culture and exposition. All original material elements should be used for the new project, e.g. exits from the villa and magnificent trees (two Norway spruces and a black pine) and non-material elements related to the representative and recreational functions in the spirit of the Ohanovichs' area, also acquired elements relating to the management functions of the entire facility. Areas highlighted in red are those which development must ensure 
the complete safety for people in the access zone. They are located at entry gates, entrances to permanently used buildings, along traffic routes and other places that will be used by people.

The second category consists of areas of great importance for the life and development of flora and fauna. Black boxes indicate areas where sightseeing and recreation will be restricted. Yellow indicates areas where, due to exceptional biocenotic values, no communication routes and places of permanent relaxation are envisaged.

This simplified plan was used to make further design decisions. In order to achieve the goal, a standard course of action adopted in the design of landscape architecture facilities was followed. As part of the pre-design activities, a series of analyses of the natural, functional, compositional, and historical arrangement were carried out.

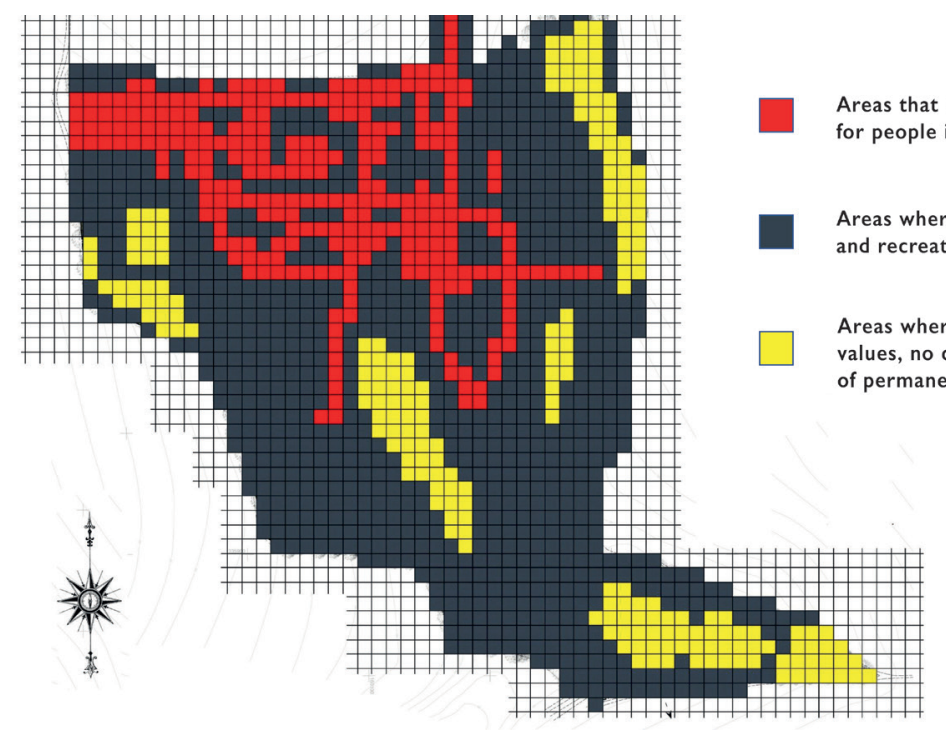

Fig. 8. Placement scheme of areas with different intensity of recreational use taking into account biocenotic values

Identification of indisputable values translates into both opportunities and threats for the area. An opportunity is undoubtedly the possibility of emphasizing the uniqueness of the place, while a threat is the necessity of maintaining and integrating certain living or inanimate elements, which do not always have a justification for their existence in a modern park. Incompetent adaptation may cause inconvenience for the user or even be perceived as a caricature. It can also significantly impoverish nature. This happens in the case of transforming the vegetation, cutting down hollow trees, thinning compact shrubs, replacing native flora with exotic plants of little value for the ecosystem and replacing permeable surfaces with more comfortable paved ones. In order to avoid the above-mentioned threats in the conceptual design of the "Vila Mîndîc" park, the extended naturalistic research was supplemented by a library query. 
It was shown that the facility had been used for many years contrary to its original function, thus many elements existing at the time of the creation of the garden by the owners who managed it before World War II were destroyed [Ozimkowska, Wojtatowicz 2016]. The lack of plans and other documents, as well as iconographic sources, authorizes the conclusion that the damage is permanent - irreversible changes have occurred. In addition, these changes were intensified in periods when both the park and the buildings were not subject to care and maintenance. Assuming that the natural values deserve special protection when using the park for recreational purposes, areas of exceptional importance for plants and animals were distinguished (Fig. 9).

- $\quad$ Ecotone between park stand and arable land (1)

- Ecotone between meadows and arable land (2)

- Ecotone between park stand and water (3)

- Fringe between park stand and park meadows (4)

- Trees and their clusters (5)

- Meadows and grasslands of high importance to animals (6)

- Marshy areas (7)

- $\quad$ Rushes (8)

Attempts were made to protect the marked areas, especially if they had trees of exceptional biocenotic value, against the future expansion of recreational forms. It was a big problem not at the moment of the qualification of a tree, which had high values, but during the design decisions. When a tree grew in a group with similar values, efforts were made to preserve the entire group, whereas dilemmas appeared when biocenotically valuable tree was found as a solitary in an area with average values from the nature and recreational point of view. In this case, the decision to set aside the tree and its surroundings as an area left to nature was contrary to the guidelines of recreational development. Such dilemmas are not faced by the designer of a typical landscape architecture object, the main goal of which is to adapt the entire area to a recreational function. From this perspective, the analysis of the remaining components and some features of the landscape, after which it was possible to make design decisions more concrete, became useful. As a result, the conceptual design of the land-use development includes many forms of recreation and leisure activities away from the most valuable areas. In areas with limited human penetration, it will be possible to observe how the preservation and floristic enrichment of parts of the park affect not only animals and funguses, but also the occurring connections between various organisms ${ }^{6}$ [Wojtatowicz 1994].

\footnotetext{
${ }^{6}$ E.g., a hollow created as a result of a broken branch and destructive activity of a fungus or carved out by a Eurasian nuthatch (Sitta europaea) will be occupied by another bird or insects.
} 


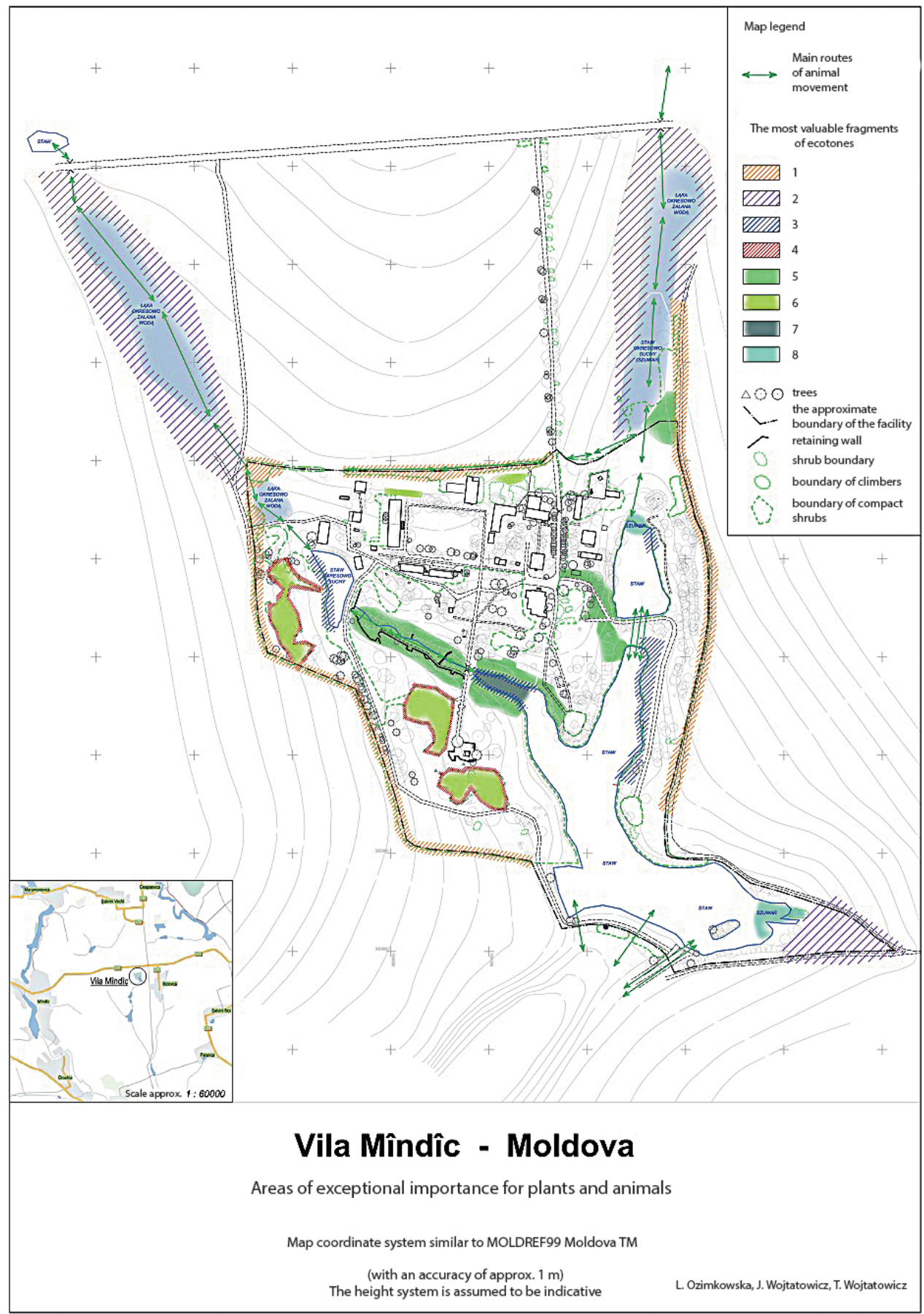

Fig. 9. Areas of exceptional importance for plants and animals 


\section{Description of the project idea of "Vila Mîndîc" park development}

The research showed that as a result of the succession process in the park many natural values appeared, which in the process of revalorization of the facility should be preserved as much as possible and used both from the point of view of recreational needs and protection of natural and cultural resources. For this reason, the concept provides elaboration of detailed designs for the areas of key importance in order to preserve the natural value of the entire site. Detailed implementation of individual solutions should take into account all biotopes, plant and animal communities important for preservation of specific values of the park. These solutions will cover the most valuable parts of tree stands, rushes, flower meadows, as well as animal migration corridors and areas of main surface water runoff after spring thaws and heavy rainfalls. The implementation of projects must be consistent with the entire concept of the assumption's revalorization, and above all, with maintaining the priority of the basic function, which is the recreation function in a historical facility. Viewing and observation points for historical, natural and landscape objects and elements are an important part the concept. As far as possible, efforts were made to locate them in former viewpoints. A number of new vantage points were also designed with new valuable features worthy of observation, including overturned or dying trees of high biocenotic value, which in many cases are picturesque. The conceptual project for the revalorization of the area includes a romantic garden and a walking park. The main element of the spatial composition of the $19^{\text {th }}$ century manorpark complex was a headland from the north, leading into the depths of the lake, from which viewing axes spread in various directions. These were: in the southern direction along the lake, in the north-eastern direction towards the left branch of the lake and in the north-western direction towards the right branch of the lake as well as towards the Elizeum, i.e. the Ohanowichs' Chapel. A distinctive element of the spatial layout is a hornbeam avenue leading to the chapel, crowned with magnificent black walnut trees.

On the conceptual project (Fig. 10), Roman numerals indicate:

I. Bay with boats mooring piers

II. Grassy beach

III. Pond for dredging

Arabic numerals indicate:

1. Observatory with a gazebo, the main viewpoint of the establishment

2. Observation from the lake slope and the eastern tree stand near the pond

3. Crossing the watercourse overlooking the pond and the dam towards the slope

4. View from the water surface on the western slope of the pond

5. A banquet glade with a lake view and a tree stand on the scarps

6. A lookout point with a view of the island and animal habitats

7. A place of relaxation with the possibility of observing fields and rushes

8. Views from the scarp of the lake and agricultural areas

9. Views of the eastern shore of the lake and the marina

10. Views of the glades with fruit trees, stately black walnut trees and the chapel 
11. View of the historic house and the terrace by the pond

12. View from the terrace of the tree stand on the western side of the pond.

Sites requiring detailed projects due to natural conditions are indicated by letters:

A. Bird nesting sites and main habitat of pond turtles proposed for protection, with access prohibited

B. Animal migration route

C. Place of water runoff and animal migration

D. Tree stands of exceptional biocenotic value

E. Flower meadows of outstanding natural values

F. Wetlands of exceptional natural values

Due to reasons beyond the team's control, the work was not continued in the following years, resulting in no detailed design projects.

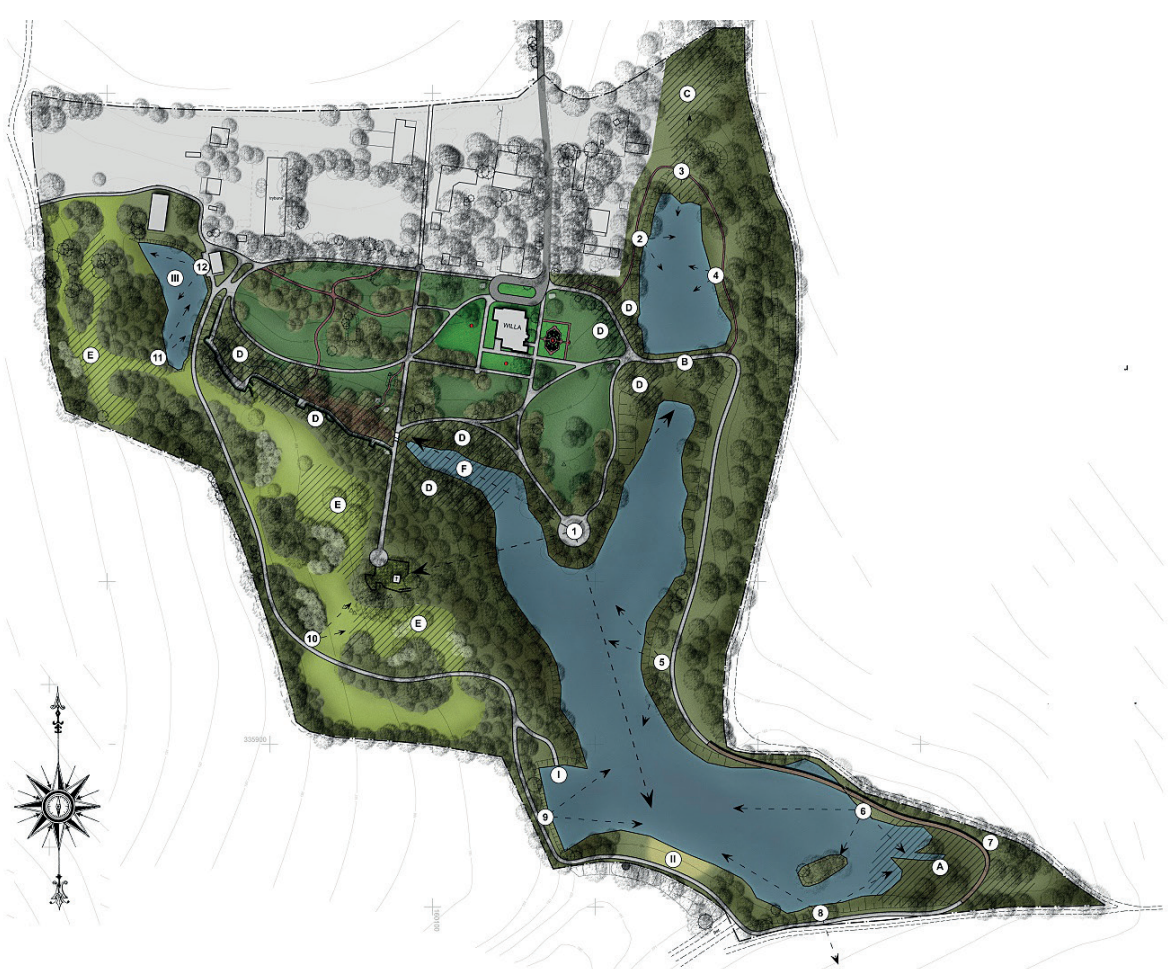

Fig. 10. Conceptual land development project 


\section{General summary and conclusions}

The application of the biocenotic tree assessment method in the pre-design works in the "Vila Mîndîc" park had a great impact on the conclusions of the conceptual land-use development project. Extending the inventory by valorisation of the trees from the point of view of their biocenotic usefulness allowed, on the one hand, to identify the most valuable sites in terms of nature, but on the other hand it revealed the conflicts between nature and culture. Thanks to the detailed identification of the biocenotic value of trees and their comparison with the health assessment and significance for nature protection, a landscape architect using such in-depth research has the opportunity to implement a project that meets the recreational needs of various user groups and preserves unique natural values that are often not comprehensively identified in contemporary facilities. As a result, some of the most attractive areas have been left to nature, and in other areas, after the project is implemented, e.g. in the immediate vicinity of the villa, the flora and fauna will certainly become impoverished.

Research with the implementation of the biocenotic tree assessment method show that there are correlations between assessment of health condition and the assessments of the biocenotic value. The dependencies and correlations between these assessments seem interesting enough to be a subject of a detailed scientific study in the field of the correlation between the results with the use of statistical methods. It was found that as the biocenotic value of a tree increases (e.g., hollow, sprouted), the human safety risk increases. Otherwise weak, dying trees have lower value than strong, healthy, abundantly flowering, fruiting trees with good nest camouflage. As trees age and grow in size, it is found that in general their biocenotic, dendrological, ecological, nature protection, historical, recreational and even aesthetic value increases. Many other bindings were noted during the pre-study phase, but not their scope of consideration. Without extended nature research, the designer is not able to predict the negative effects of his actions. It seems that application of the biocenotic tree assessment method, although it is time-consuming and requires the use of design decisions at the analysis stage, leads to optimal use of the site. Taking into account the methodological assumptions, the valorisation of trees in "Vila Mîndîc" park fully met the requirements of the extended dendrological analysis, although it showed the complexity of problems associated with its results. The conducted research is a kind of a case study. A similar analysis completed by the project could be the subject of further research. 


\section{References}

Dormidontovna. V.V., 1992, Historyczna charakterystyka i stan wspótczesny starych parków Motdawii, Garmoiâ iskustva i prirody, Kišinev.

Dujanowicz K., Werner B., 2013, Analiza możliwości adaptacji obiektu polskiego dziedzictwa narodowego: założenia architektoniczno-parkowego "Willa Mindic" na międzynarodowe centrum pogranicza narodowościowego w Mołdawii, pokaz, Ministerstwo Kultury i Dziedzictwa Narodowego, Departament Dziedzictwa Kulturowego.

Leontjew P., 1967, Parki Moldavii, Kišinev.

Luniak M, Węgrzynowicz A., 2019, Wptyw renowacji parków miejskich na ich awifaunę lęgowqprzykład z Warszawy, Chrońmy Przyrodę Ojczysta, 75, 1, pp. 3-15.

Kravčuk O.P.,1972, Zapovednye i rekomenduemye $k$ zapovedenû cennye raspisnye obekty $v$ raenah Srednego Pridnestovâ, Ohrona prirody Moldavii, 10.

Michałowski A., Werner B., 2014, Wstępne wytyczne konserwatorskie w sprawie rewaloryzacji i zagospodarowania założenia dworsko-parkowego "Willa Mindic” w Mołdawii. Praca zlec. Fundacja Dziedzictwa Kulturowego, Warszawa.

Monitorul Oficialal. Republicii Moldova, 18, 20 martie 1997, MOLDPRES.

Ozimkowska L., Wojtatowicz J., 2016, Zespót dworsko-parkowy „Willa Mindic” jako szczególny element w krajobrazie i przemiany jego struktury jako znaków czasu, MAZOWSZE Studia Regionalne, 18, Mazowieckie Biuro Planowania Regionalnego, Warszawa, pp. 49-69.

Ozimkowska L., Wojtatowicz J., 2020, Metoda waloryzacji drzew ze względu na ich wartości biocenotyczne, MAZOWSZE Studia Regionalne, 32, Mazowieckie Biuro Planowania Regionalnego, Warszawa, pp. 123-136.

Ozimkowska L., Wojtatowicz J., Jancelewicz R., 2014, Prace rewaloryzacyjne przy ogrodzie Vila Mindyc Mołdawia (Vila Mîndîc, Moldova). Inwentaryzacja drzewostanu. Praca zlec. Fundacja Dziedzictwa Kulturowego, Warszawa.

Ozimkowska L., Wojtatowicz J. Szczepanik A., 2015, Prace rewaloryzacyjne przy ogrodzie Vila Mindyc, Mołdawia (Vila Mîndîc, Moldova) - etap II, ekspertyza wykonana na zlecenie Fundacji Dziedzictwa Kulturowego, Warszawa.

Pasport pamâtniki istorii i kultury SSSR.

Pepko J., 2008, Skutki przyrodnicze modernizacji parku Keppa Potocka w Warszawie, Turystyka i Rekreacja, 4, pp. 29-36.

Soloveva T., 2002, Tainy Villi Myndyk, Novoe vremâ 28 iûnâ 2002, 24.

Taras Â.N., 1986, Pamâtniki arhitektury Moldavii (XVI- načalo XX veka). 
Theodorowicz L., 1925, Nieco o heraldyce i rodach Ormian polskich, nakładem autora, Lwów.

Wojtatowicz J., 1994, Avifauna miejskich parków historycznych [in:] Materiały Sympozjum: Dziedzictwo miejskich ogrodów i krajobrazu historycznego, Katedra Urządzania i Pielęgnacji Krajobrazu SGGW, Ośrodek Ochrony Zabytkowego Krajobrazu, Warszawa Ursynów.

Wojtatowicz J., 2010, Ocena drzew szczególnych w krajobrazie [in:] B. Szulczewska, M. Szumański (ed.), Horyzonty Architektury Krajobrazu. Metoda architektury krajobrazu, SGGW w Warszawie, Urząd Miasta Stołecznego Warszawy. Wyd. „Wieś Jutra”, Warszawa.

www.brueldelmar.fr / fr/project/ 22 / parc-ecologique-de-saint-jacques [access 28.02.2021 r.].

www.dziedzictwo.org/Działalność/ zespół-dworsko-parkowy-vila-mindic-moldawia [access 28.02.2021 r.]. 


\section{Zastosowanie metody biocenotycznej oceny drzew w parku „Willa Mindic” (Mołdawia) na potrzeby wykonania projektu koncepcyjnego zagospodarowania terenu - studium przypadku}

\section{STRESZCZENIE}

W artykule przedstawiono zastosowanie metody oceny biocenotycznej drzew w parku „Willa Mindic" (Mołdawia). Przeprowadzając inwentaryzację uwzględniano wstępne decyzje projektowe, które także miały wpływ na określenie wartości drzew. Rozszerzając waloryzację roślin o badanie stanu zdrowotnego, w tym bezpieczeństwa dla ludzi, uzyskano wyniki, które służyły do wykonania projektu. Wytypowano miejsca, które bez względu na warunki muszą zapewnić bezpieczne przebywanie, fragmenty terenu, na których zwiedzanie parku jest ograniczone oraz te, na których ze względu na wysokie wartości biocenotyczne, $\mathrm{w}$ tym ochronę miejsc lęgu i rozrodu zwierząt, nie przewiduje się ciągów komunikacyjnych i miejsc wypoczynkowych. Na podstawie badań wskazano obszary o wyjątkowym znaczeniu dla zwierząt oraz wykonano projekt koncepcyjny zagospodarowania terenu uwzględniajacy potrzeby wypoczynkowe ludzi.

Słowa kluczowe: architektura krajobrazu, dendrologia, wartości biocenotyczne drzew, powiązania przyrodnicze 